\title{
Colour variation in the common hamster Cricetus cricetus in the north-eastern foot-hills of the Harz Mountains
}

\author{
Anja KAYSER and Michael STUBBE
}

\begin{abstract}
Kayser A. and Stubbe M. 2000. Colour variation in the common hamster Cricetus cricetus in the north-eastern foot-hills of the Harz Mountains. Acta Theriologica 45: 377-383.

We investigated the occurrence of colour variations in the common hamster Cricetus cricetus (Linnaeus, 1758) between 1915 and 1980 in the north-eastern foot-hills of the Harz Mountains in Saxony-Anhalt. Material was collected by a professional hamster trapper. The most frequent colour variants were white hamsters followed by piebald and yellow animals. The occurrence of colour morphs was strongly male biased. Only one black hamster, probably an atypical melanistic form, was found in the entire sample of 73657 hamsters. Overall the percentage of variant individuals was $0.0855 \%$. The frequency decreased significantly over the observed period. Investigations during the 1990s in a neighbouring area showed no colour variation in a smaller sample set. A possible connection between the decline in hamster numbers during this period in the study area and the reduced frequency of colour morphs is discussed.
\end{abstract}

Institute of Zoology, Martin-Luther-University Halle-Wittenberg, Domplatz 4, PF University, D-06099 Halle/S., Germany, e-mail: kayser@zoologie.uni-halle.de

Key words: Cricetus cricetus, colour variations, population decline, Germany

\section{Introduction}

The common hamster Cricetus cricetus (Linnaeus, 1758) with its red-brown to grey-brown back and black belly, white patches on snout, cheeks, shoulder, upper thigh, dorsal surface of feet, lips and ear edges is one of the most colourful animal species of the European fauna. Within this normal coloration, considerable colour variations occur. A white spot on the breast is often found in the western distribution area, but rather infrequent in the eastern distribution area (Niethammer 1982). Melanism is typical for Thuringia, Bashkiria and Ukraine (Zimmermann 1969, Vorontsov 1982). Such black hamsters show white ear edges, feet and snout. A single melanistic hamster was also found in the Magdeburger Börde district of Germany (Weber 1973). Very dark "atypical melanistic" hamsters have been recorded from the northern foot-hills of the Harz Mountains, near Dresden and Rheinhessen (Petzsch 1958, Thomas 1963, Zimmermann and Handtke 1968). The colouration of these hamsters ranged from slightly darker than normal, with occasional remnants of the normal colouration (eg light spots), to intense black. Black hamsters without clear description are reported from Silesia, Zörbig and other areas which probably belong to the same atypical melanistic form (Schlott 
1923 in Petzsch 1936, Petzsch 1939, Zimmermann and Handtke 1968). Bechstein (1801) and later Petzsch $(1949,1950)$ also mentioned pure albinos, white animals with dark eyes, yellow ones (flavistic), piebald individuals and partial albinos. Besides white, yellow, red and black, all kinds of intermediates like sand coloured or "iron grey" were found (Petzsch 1950, 1960). Little information about the frequency of colour variations is available. Only melanistic forms can accumulate due to their dominant inheritance pattern (Gershenson and Polevoi 1940, Petzsch 1940 in Petzsch and Petzsch 1956). In contrast to other colour variations, melanistic hamsters seem to have fitness and vitality similar to normal coloured hamsters (Petzsch and Petzsch 1956). In the Ukraine there are areas with a melanic frequency of over 80\% (Gershenson 1945 in Vorontsov 1982, Kirikov 1934 in Petzsch and Petzsch 1956), in Thuringia up to 15\% (Stengel 1932) respectively between 0.5 and $18 \%$ (Zimmermann 1969). The existence of subpopulations with melanism frequencies up to $50 \%$ was revealed in Thuringia (Zimmermann 1969).

Other colour variations seem to be unique peculiarities. Reports date back to the times of intensive hamster trapping and control, when the species was a serious pest to agriculture (Müller 1956, Jüttner 1957). The present status of the species in central and western Europe is characterized by an enormous decline even in its main distribution areas like the Börde region in Germany (Seluga and Stubbe 1997, Weidling 1997, Weidling and Stubbe 1997b).

In this study, data collected throughout his life by the hamster trapper Richard Marscheider from Friedrichsaue in the north-eastern foot-hills of the Harz Mountains at the edge of the Magdeburger Börde were analysed with regard to colour variations and their frequency, and compared with the current situation.

\section{Material and methods}

Trapping records by Richard Marscheider in the area of Friedrichsaue and neighbouring villages between 1915 and 1980 were analysed. Altogether, he trapped 73657 hamsters in this period. All colour variations were recorded and, until 1942 (with the exception of 2 years), also the sex of the variants. Results were compared with data from a recent hamster recapture study carried out around the Hakel. Methods of live trapping of common hamsters have been described by Weidling and Stubbe (1997a) and Weidling (1997). The investigation areas are a short distance from each other in the north-eastern foot-hills of the Harz Mountains at the southern edge of the Magdeburger Börde district in Saxony-Anhalt, Germany. Deep chernozems to brown earth chernozems of loess and an annual rainfall of about $500 \mathrm{~mm}$ are typical for this region. Regression analysis was carried out using the program Statistica.

\section{Results and discussion}

\section{Frequency of colour variations}

In Marscheider's material white, yellow, black and piebald hamsters were recorded as colour variations comprising $0.0855 \%$ (Table 1 ). 
Table 1. Number and frequency of colour variations in the total number of 73657 hamsters trapped near Friedrichsaue (east Germany) in the period $1915-1980$

\begin{tabular}{lrc}
\hline Colour variation & Number & Frequency $(\%)$ \\
\hline White & 50 & 0.0679 \\
Piebald & 7 & 0.0095 \\
Yellow & 5 & 0.0068 \\
Black & 1 & 0.0014 \\
Total & 63 & 0.0855 \\
\hline
\end{tabular}

The most frequent variants were white hamsters, followed by piebald and yellow (flavistic) animals. A black hamster was found only once (in 1924), and noted as a peculiarity. It was probably not a true melanic but a rather dark atypical form. Nowadays these variations are also called "black" by the hamster trappers in this region. It was impossible to identify white hamsters as true albinos or white hamsters with black eyes (leucism). It might be that both forms were included in the white category. The term "colourful" presumably means variegated or piebald hamsters, because the trapper specifically mentioned it as a colour variation.

A similar frequency of white hamsters $(0.083 \%)$ was found in the 4800 animals trapped in Giersleben (district Bernburg in Saxony-Anhalt) (Stubbe et al. 1998). Weber (1973) obtained mainly albinos and flavistic hamsters, but only one black form (typical melanism) from hamster trappers of the district Haldensleben at the northern edge of the Magdeburger Börde. Flavistic hamsters were here often accumulated around a village or a locality. Such colour variation used to be more frequent in former times in certain districts of Saxony-Anhalt (Petzsch and Petzsch 1956). Hamster furs bought by the company Gustav Meyer from Haldensleben (Saxony-Anhalt) included fewer piebald hamsters than white or black hamsters (Petzsch 1936).

The frequency of colour variation in Marscheider's data is very low compared with other published information, but it is the first investigation of such extensive material from a restricted area over a long period. Frequencies of colour variation were often recorded only in fur collecting centres. Such records do not necessarily represent the frequency in natural populations and are often without clear temporal or side data. For example in Austria, Bauer (1960) reported from a fur collecting company $0.3-1.0 \%$ atypical melanistic furs, which were twelve times more frequent than albinotic or flavistic ones. High frequencies of atypical melanistic hamsters are also given by Zimmermann and Handtke (1968) for some areas in the Magdeburger Börde, eg $0.05 \%$ of 4000 hamsters trapped in the village Groß-Börnicke. The frequency of colour variation obviously varies locally. Even dominantly transmitted melanism can vary considerably in frequency in neighbouring villages (Zimmermann 1969). 
The frequency of colour variation in our data collected over 65 years is similar to the spontaneous mutation rate of fur colour genes in the house mouse Mus musculus (Schlager and Dickie in Strickberger 1988). Albinotic and yellow forms are recessive in contrast to the dominant normal and melanic types (Petzsch and Petzsch 1956). The black and yellow forms belong probably to the E (Extension) series of the multiple allelomorphic system (Petzsch and Petzsch 1956, Searle 1968). The status and genetic background of albinism and other white and piebald forms of Cricetus cricetus is uncertain (Petzsch and Petzsch 1956).

\section{Sexual differences in colour variation}

The sex of 19 colour variations was recorded. All but one are males. The hamster trapper had practised selective trapping of males, so that about $80 \%$ males and $20 \%$ females were trapped. The frequency of the white colour variation is higher among males than females (Table 2). The only black hamster from the same period was also a male.

Data in the literature are insufficient to decide if there is really a higher frequency of colour variations in males.

Table 2. Sexual differences in the frequency of the white colour variation.

\begin{tabular}{lcc}
\hline Sex & Number & $\begin{array}{c}\text { Frequency per trapped hamster } \\
\text { of the same sex }\end{array}$ \\
\hline Females & 1 & 0.037 \\
Males & 17 & 0.172 \\
\hline
\end{tabular}

\section{Temporal changes of colour variation frequency}

Different years were combined in five-year periods to compare the frequency of colour variation (Fig. 1). In the first few years only a few hamsters were trapped. Therefore the first year has been excluded from the further analysis and thirteen five-year sets of data were obtained.

The frequency of colour variation decreases over the whole observed period (Fig. 2). An exception is in 1971-1975 when few hamsters were trapped because of the population decrease. A regression analysis gives a significant reduction at the 5\% level with a correlation coefficient of $r=-0.62$ (Fig. 2). These data support the observations of other trappers who report a general decrease of colour variations, with none in the last decades (K. Schufft, E. Minstedt pers. comm.).

Only one male a little darker than usual was caught among 305 trapped hamsters in a capture-mark-recapture study in the neighbouring Hakel area between 1994 and 1999. Its colouration was only a little bit darker than normal and could only be recorded through direct comparison with a normal coloured hamster. 

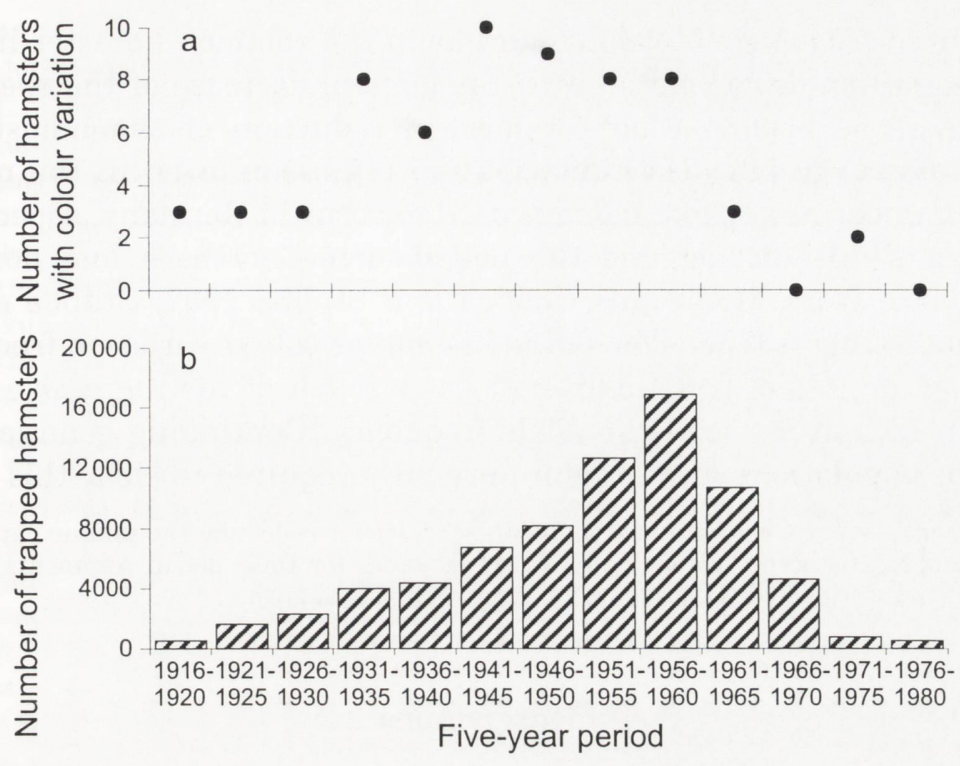

Fig. 1. Number of colour variations (a) and total number of trapped hamsters (b) in different five-year periods.

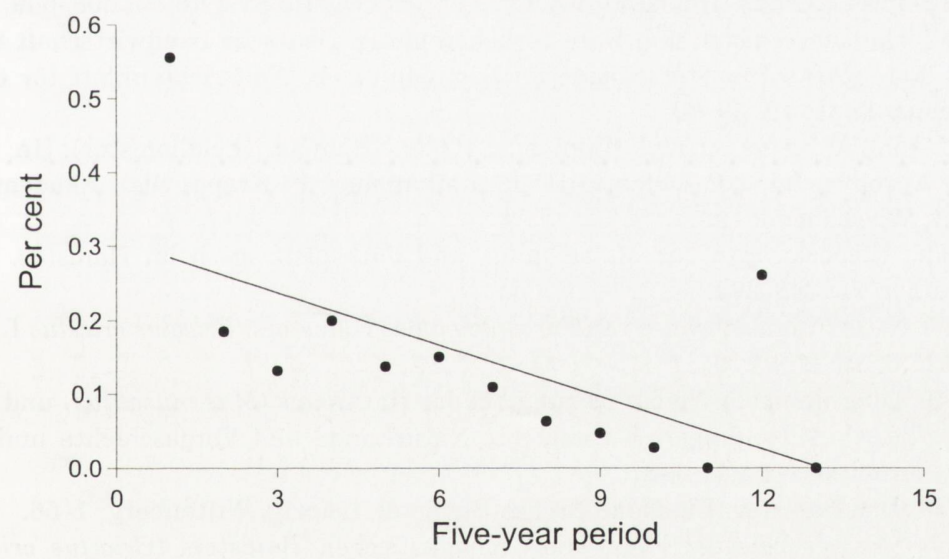

Fig. 2. Frequency of colour variation from 1916 to 1980 ; regression: $x=0.308-0.023 y$, correlation: $r=-0.62, p<0.05$.

No other colour variations were observed. It is rather unlikely that such a small variant would have been recorded by $\mathrm{R}$. Marscheider as a black hamster. Only much darker animals than usual are recorded by other trappers as black. This means that no record of a real colour variant has been obtained in the nineties. 
The reduced frequency of colour morphs in the common hamster in the study area in this century is correlated with the general decrease of the species in this period. There has been not only a marked reduction of the hamster density throughout its range but also a distribution regression even in the main distribution and damage area. Most damage used to occur in Germany, especially in the Magdeburger Börde district and the neighbouring northern and north-eastern foot-hills of the Harz Mountains (Seluga and Stubbe 1997, Stubbe et al. 1997, Weidling and Stubbe 1997b). The fall in phenotype colour variation frequency may reflect an overall loss of genetic diversity as a result of the regressive population development or a decrease of the allele frequency. Continuing genetic studies on the remnant populations are therefore urgently required to clear this point.

Acknowledgements: We are very grateful to R. Marscheider for collecting the unique data. We want to thank S. Hauer, K. Neumann and two anonymous referees for their useful comments on an earlier version of the manuscript and K. Williams for improving the English.

\section{References}

Bauer K. 1960. Säugetiere des Neusiedlersee-Gebietes. Bonner zoologische Beiträge 11(2-4): 141-342. Bechstein I. M. 1801. Hamster. [In: Gemeinnützige Naturgeschichte Deutschlands nach allen drey Reichen. I. M. Bechstein, ed]. Siegfried Lebrecht Crusius Verlag, Leipzig: 1005-1026.

Gershenson S. and Polevoi V. V. 1940. Inheritance of black colour in the Common hamster (Cricetus cricetus). Comptes Rendus (Doklady) Academie of Sciences URSS 29(8-9): 608-609.

Jüttner P. 1957. Hamsterschäden und Hamsterbekämpfung. Deutsche Landwirtschaft 8(4): 201-202.

Müller K. R. 1956. Starke Hamsterschäden an Sonnenblumen. Nachrichtenblatt für den Deutschen Pflanzenschutzdienst 10: 59-60.

Niethammer J. 1982. Cricetus cricetus (Linnaeus, 1758) - Hamster (Feldhamster). [In: Handbuch der Säugetiere Europas, Bd. 2/I, Rodentia II. J. Niethammer, F. Krapp, eds]. Akademische Verlagsgesellschaft, Wiesbaden: 7-28.

Petzsch H. 1936. Bemerkungen zur Melanismus- und Farbspielfrage beim Hamster. Zeitschrift für Säugetierkunde 11: 343-344.

Petzsch H. 1939. Neue Fundnachweise von Farbspielen des Hamsters (Cricetus cricetus L.). Zoologischer Anzeiger 125(9/19): 269-270.

Petzsch H. 1949. Über anomale Weißscheckung bei der Hausmaus (Mus musculus) und beim Hamster (Cricetus cricetus). Mitteilungen Museum für Naturkunde und Vorgeschichte und Naturwissenschaftlicher Arbeitskreis 2(1): 1-8.

Petzsch H. 1950. Der Hamster. Die Neue Brehm-Bücherei, Leipzig, Wittenberg: 1-56.

Petzsch H. 1958. Erster belegter Fund eines melanistischen Hamsters (Cricetus cricetus) aus der Umgebung von Dresden. Säugetierkundliche Mitteilungen 6: 78-79.

Petzsch H. 1960. "Eisengraues" Farbspiel des Hamsters (Cricetus cricetus cricetus Linné, 1758). Zoologischer Anzeiger 165(11/12): 418-422.

Petzsch H. and Petzsch H. 1956. Zum Problem des Vererbungsmodus für Melanismus bei dem gemeinen Hamster (Cricetus cricetus L.) in Hinsicht auf die Evolution. Zoologischer Garten N. F. 22(1/3): 119-154.

Searle A. G. 1968. Comparative genetics of coat colour in mammals. Academic Press, London: 1-308.

Seluga K. and Stubbe M. 1997. Zur Bestandssituation des Feldhamsters (Cricetus cricetus L.) in Ostdeutschland. Säugetierkundliche Informationen 21: 255-264.

Stengel E. 1932. Die Verbreitung des Hamsters und des wilden Kaninchens in Thüringen. Jenaer Zeitschrift für Naturwissenschaften 67: 181-198. 
Strickberger M. W. 1988. Genetik. Carl Hanser, München, Wien: 1-843.

Stubbe M., Seluga K. and Weidling A. 1997. Bestandssituation und Ökologie des Feldhamsters Cricetus cricetus (L., 1758). Tiere im Konflikt 5: 5-60.

Stubbe M., Stubbe A. and Weidling A. 1998. Der Feldhamster im Spiegel von Presse und Ämtern, von Vernichtungs- und Naturschutzstrategien. [In: Ökologie und Schutz des Feldhamsters. M. Stubbe and A. Stubbe, eds]. Wissenschaftliche Beiträge Martin-Luther-Universität Halle-Wittenberg, Halle/Saale: $333-416$.

Thomas E. 1963. Melanistische Hamster, Cricetus cricetus L., aus Rheinhessen. Zeitschrift für Säugetierkunde 28: 43-47.

Vorontsov N. N. 1982. [Fauna of the U.S.S.R. Mammals III (6)]. Nauka, Leningrad: 1-388. [In Russian] Weber B. 1973. Erstnachweis eines Hamsters Cricetus c. cricetus L. mit typischem Melanismus für die Magdeburger Börde. Hercynia N. F. 10: 161.

Weidling A. 1997. Zur Raumnutzung beim Feldhamster im Nordharzvorland. Säugetierkundliche Informationen 21: 265-273.

Weidling A. and Stubbe M. 1997a. Fang-Wiederfang-Studie am Feldhamster Cricetus cricetus L. Säugetierkundliche Informationen 21: 299-308.

Weidling A. and Stubbe M. 1997b. Der Feldhamster - Überleben in der intensiv genutzten Agrarlandschaft. [In: Einfluss der Großflächen-Landwirtschaft auf die Fauna]. Thüringer Ministerium für Landwirtschaft, Naturschutz und Umwelt, Erfurt: 34-37.

Zimmermann W. 1969. Die gegenwärtige Verbreitung melanistischer Hamster (Cricetus cricetus L.) in Thüringen und Bemerkungen zu deren Morphologie. Hercynia N. F. 6: 80-89.

Zimmermann W. and Handtke K. 1968. Atypischer Melanismus beim Gemeinen Hamster Cricetus c. cricetus L. im Nördlichen Harzvorland und in der Magdeburger Börde. Hercynia N. F. 5: 1-6.

Received 10 May 1999, accepted 26 October 1999. 